\title{
Gonadal defects and hormonal alterations in transgenic mice expressing a single chain human chorionic gonadotropin-lutropin receptor complex
}

\author{
Thomas P Meehan, Barry G Harmon', Megan E Overcast, Kristine K Yu, Sally A Camper², \\ David Puett and Prema Narayan
}

Department of Biochemistry and Molecular Biology, University of Georgia, Athens, GA 30602, USA

${ }^{1}$ Department of Pathology, College of Veterinary Medicine, University of Georgia, Athens, GA 30602, USA

${ }^{2}$ Department of Human Genetics, University of Michigan, Ann Arbor, MI 48109, USA

(Requests for offprints should be addressed to Prema Narayan; Email: narayan @ bmb.uga.edu)

(Thomas P Meehan is now at Department of Molecular and Human Genetics, Baylor College of Medicine, Houston, TX 77030, USA)

(Megan E Overcast is now at Department of Molecular Genetics, Bowman Gray School of Medicine, Wake Forest University, Winston-Salem, NC, USA)

\begin{abstract}
To study the effects of premature and chronic ligand-mediated luteinizing hormone receptor (LHR) activation on reproductive development, we have generated transgenic mice expressing a genetically engineered, constitutively active yoked hormone-receptor complex (YHR), in which a fusion protein of human chorionic gonadotropin (hCG) is covalently linked to the $\mathrm{N}$-terminus of rat LHR. YHR-expressing mice $\left(\mathrm{YHR}^{+}\right)$were analyzed at pre- and post-pubertal ages. Relative to wild type (WT) controls, male mice exhibited prepubertal increases in testosterone levels and seminal vesicle weights, and decreases in serum FSH, serum $\mathrm{LH}$, testes weight, and the size of the seminiferous tubules. In adult male $\mathrm{YHR}^{+}$mice, testosterone and LH levels are not significantly different from WT controls. However, FSH levels and testes weights remain decreased. Female $\mathrm{YHR}^{+}$mice undergo precocious puberty with early vaginal opening, accelerated uterine development, enhanced follicular development, including the presence of corpora lutea, and an increase in serum progesterone. At 12 weeks of age, the ovary exhibits a relative increase in the amount of interstitial tissue, comprised of cells that are hypertrophic and luteinized, as well as follicles that are degenerating. Additionally, hemorrhagic cysts develop in approximately $25 \%$ of the transgenic mice. These degenerative changes are consistent with an aging ovary suggesting that CG-induced LHR activation in female mice leads to precocious sexual development and ovarian lesions. Taken together, these data indicate that the single chain YHR is functional in vivo and demonstrate that $\mathrm{YHR}^{+}$mice provide a novel system to further understand the reproductive consequences of aberrant LHR activation.
\end{abstract}

Journal of Molecular Endocrinology (2005) 34, 489-503

\section{Introduction}

Human chorionic gonadotropin (hCG), luteinizing hormone (LH), and follicle-stimulating hormone (FSH) comprise the family of gonadotropin hormones which are heterodimeric glycoproteins consisting of a common $\alpha$-subunit and a hormone specific $\beta$-subunit (Hearn \& Gomme 2000). The $\beta$-subunits of LH and hCG have high sequence identity, differing mainly in the 30 amino acid C-terminal peptide of hCG that is absent in LH. These hormones signal through a common member of the glycoprotein hormone receptor superfamily of G-protein coupled receptors, the LH receptor (LHR), characterized by seven transmembrane domains and a large extracellular domain that confers hormone binding specificity. LHR signals primarily through the cAMP pathway, although high levels of hormone can mediate signal transduction via the inositol phosphate pathway (Ascoli et al. 2002). LHR, which is essential for reproduction in mammals, is expressed primarily in the Leydig cells of the testes and in the theca and granulosa cells of developing follicles, as well as luteal cells, in the ovaries. LH secretion from the pituitary and subsequent activation of LHR in the Leydig cells at the onset of puberty promotes testosterone synthesis, required for the secondary sexual characteristics in males. In females, LHR activation is required for estrogen synthesis, and an LH surge from the pituitary triggers ovulation and luteinization of the granulosa cells to form the corpus luteum (Robker et al. 2000).

As part of our ongoing structure-function studies on hCG and LHR we have previously engineered a yoked hormone-receptor complex (YHR) by covalently linking a single chain or yoked hGG (YhCG) 
(Narayan et al. 1995, Sugahara et al. 1995), containing the two subunits of the heterodimeric hCG, with rat LHR in a single polypeptide chain $(\mathrm{Wu}$ et al. 1996). When expressed in HEK 293 and COS-7 cells, YHR exhibits signaling characteristics of a constitutively active receptor with increases in basal levels of cAMP approximately 20-25-fold over that of LHR and is not further stimulated by the addition of exogenous hCG (Wu et al. 1996). Additonally, YHR also increases basal levels of inositol phosphate (TP Meehan, D Puett and P Narayan, unpublished observation).

In order to determine if YHR was functional in vivo and to examine the physiological effects of chronic gonadotropin-mediated LHR activation, we have generated transgenic mice expressing YHR under the control of the mouse inhibin $\alpha$-subunit promoter. This promoter was chosen because of its documented success in targeting transgenes to the gonads of mice (Hsu et al. 1995, Kananen et al. 1996), particularly to the Leydig/Sertoli cells of the testes and the theca/granulosa cells of the ovary. The LHR promoter sequence that directs both testicular and ovarian expression in transgenic mice remains to be identified (Hamalainen et al. 1999, 2001). Additionally, we generated mice expressing rat LHR containing a histidine mutation at aspartic acid residue 556 $(\mathrm{D} 556 \mathrm{H})$ in transmembrane helix 6. LHR with this mutation is constitutively active in cell culture in a ligand-independent manner, resulting in elevated levels of cAMP and inositol phosphate (Liu et al. 1999, Angelova et al. 2002). This mutation has also been identified as a somatic mutation in boys that have testosterone-secreting Leydig cell adenomas and consequently also present with precocious puberty (Liu et al. 1999, Canto et al. 2001). Therefore, the two receptors provide complementary systems of receptor activation, YHR being ligand mediated and D556H LHR being ligand independent. Unlike previous studies of transgenic mice overexpressing LH or hCG (Risna et al. 1995, Rulli et al. 2002, 2003, Matzuk et al. 2003), the transgenic mice expressing YHR and D556H LHR will provide models for premature activation of LHR under physiological levels of circulating LH. To our surprise, male and female founder mice expressing D556H LHR were infertile, and a detailed characterization of this transgenic line was not performed. Herein, we describe, for the first time, establishment and phenotypic characterization of transgenic mice expressing a constitutively active LHR $\left(\mathrm{YHR}^{+}\right)$. Our studies show that male and female $\mathrm{YHR}^{+}$mice exhibit multiple reproductive defects and suggest that the $\mathrm{YHR}^{+}$mice may be a good model to understand the role of premature LHR signaling in gonadal development and female reproductive senescence.

\section{Materials and methods}

\section{Generation of transgenic mice}

YHR and D556H rLHR-myc were cloned under the control of the $6 \mathrm{~kb}$ mouse inhibin $\alpha$-subunit promoter (Fig. 1A). PGR products were generated from YHR in pcDNA3 (3317 bp) and D556H rLHR-myc in pcDNA3 (2617 bp) containing the coding sequence for the receptors and the bovine growth hormone polyadenylation signal (bGHpA) with Nhe I restriction sites added to each end. A partial digest was performed on an inhibin- $\alpha /$ bcl-2 in pBluescript-SK (-) construct (kindly provided by Dr Aaron Hsueh, Stanford University, CA USA) with Xba I to remove the bcl-2 coding sequence. The PCR products were digested with Nhe I and inserted into the Xba I site of the vector. Following a Cla I digest and gel purification to remove the prokaryotic sequences, the transgene was microinjected into (C57BL/6 xSJL) F2 fertilized eggs. Potential founders born following implantation into a pseudopregnant female were genotyped by PCR and Southern blot analysis of DNA extracted from tail biopsies. Genotyping of YHR mice was performed with forward PCR primers designed to anneal to the $\alpha$-subunit of hCG in YHR (5' CAGAGTCGACTTGCTGTGTAGCTAA ATC $3^{\prime}$ ) and the reverse primer to the extracellular domain of LHR (5' CATACAGTTTTACTGTGACA GACTCGTTA $3^{\prime}$ ). Genotyping of D556H LHR mice was done with primers that annealed to the myc sequence (5' GCTTATTTCTGAAGAAGACTTGCG AGAGCTGTCAG $3^{\prime}$ ) and the extracellular domain of LHR (5' TGGAAGGGTCGACTGTGCATCTTCTC CAGGTA $3^{\prime}$ ). The PGR reactions were performed using HotStart Taq polymerase (Qiagen, Valencia, CA, USA) and the PCR cycle conditions were as follows: $95{ }^{\circ} \mathrm{C}$ for $15 \mathrm{~min} ; 35$ cycles at $95^{\circ} \mathrm{C}$ for $30 \mathrm{~s}, 60{ }^{\circ} \mathrm{C}$ for $1 \mathrm{~min}, 72{ }^{\circ} \mathrm{C}$ for $1 \mathrm{~min}$ with a final extension step at 72 ${ }^{\circ} \mathrm{C}$ for $10 \mathrm{~min}$.

\section{Establishment of transgenic lines}

Microinjection of the transgenes generated eight transgenic founder mice each for YHR (five male, three female) and D556H (three male, five female). Founder mice were bred to C57BL/6J mice (Jackson Laboratory, Bar Harbor, ME, USA), and N1 progeny were tested for the transmission of the transgene by PCR. Tissuespecific expression of the transgene was determined by RT-PCR. Transgenic lines could not be established from D556H LHR founder mice because the mice did not reproduce $(n=4)$, transmit the transgene $(n=2)$, or express the receptor $(n=2)$. A limited analysis of these mice at 8 months of age showed that the testicular weights of the two males that expressed the receptor were lower than control mice. Female founder mice were in a state of persistent diestrus and interstitial cell 
hypertrophy; follicular cysts and corpora lutea (CLs) were evident in the ovaries of these mice.

YHR founder mice were all fertile with five of eight transmitting the transgene and four of eight expressing the receptor in the gonads and adrenals of $\mathrm{N} 1$ progeny. RNA samples from the testes and adrenals of YHR-expressing lines were subjected to semiquantitative RT-PCR in order to identify lines of mice for further study. Two lines were chosen which had high and similar levels of YHR expression in the gonads and low levels of adrenal expression. The two lines exhibited similar phenotypes, and the data presented are from the $\mathrm{N} 5$ to $\mathrm{N} 8$ generations in the C57BL/6J background of one of these lines. Female mice were subfertile and male $\mathrm{YHR}^{+}$mice were bred to maintain the line. The onset of puberty was determined as the first day of vaginal opening as investigated daily beginning at day 21 (day of birth is day 1). Cycling studies were performed by analyzing daily vaginal smears for a period of 3 weeks.

All mice were maintained in a conventional colony with a 12-h light, 12-h dark cycle. They were provided with standard laboratory chow (Purina 5001, LabDiet, Richmond, IN, USA) and tap water ad libitum. All animal studies were approved by the Institutional Animal Care and Use Committee at the University of Georgia.

\section{RNA isolation, RT-PCR, and semi-quantitative RT-PCR}

Total RNA was collected from each tissue after homogenization with a Kontes homogenizer in RNA Stat-60 (Tel-test, Inc., Friendswood, TX, USA). Following treatment with DNase I (DNA free, Ambion, Austin, TX, USA) for $30 \mathrm{~min}$ at $37^{\circ} \mathrm{C}, 2 \mu \mathrm{g}$ of each RNA sample was subjected to reverse transcription (RT) utilizing the Retroscript kit (Ambion). PCR was performed on $1 / 4$ of the RT reaction for 30 cycles (30 s at $95{ }^{\circ} \mathrm{C}, 1 \mathrm{~min}$ at $60{ }^{\circ} \mathrm{C}, 1 \mathrm{~min}$ at $72^{\circ} \mathrm{C}$ ) using primers for YHR, D556H LHR, or mouse glyceraldehyde phosphate dehydrogenase (mGAPDH). To ensure specificity of the PCR, reactions without reverse transcriptase and without template were performed. PCR products were resolved on a $1.5 \%$ agarose gel in Tris-borate-EDTA (TBE) buffer, stained with ethidium bromide and visualized by u.v.

For semi-quantitative RT-PGR, the PGR reactions were carried out in the presence of $\alpha_{-}{ }^{32} \mathrm{P}-\mathrm{dCTP}$ (Perkin Elmer, Boston, MA, USA) utilizing the QuantumRNA Classic II 18S internal standard kit (Ambion). Reactions were multiplexed with primers for YHR and $18 \mathrm{~S}$ rRNA. Pilot experiments were performed to determine the cycles at which a linear range of amplification is achieved and to attenuate the 18S rRNA signal to the level of the YHR signal such that each would be in the linear range of amplification at the same cycle. PCR products were visualized utilizing a phosphorimager (Molecular Dynamics, Amersham Corporation, Piscataway, NJ, USA) following resolution on a $6 \%$ acrylamide gel in TBE buffer. Relative expression levels are given as a ratio of YHR signal to 18S rRNA signal and normalized to $1 \cdot 0$ for the lowest level.

Real-time RT-PCR was performed on an I-Cycler (Biorad, Hercules, CA, USA) utilizing a Sybr green PCR master mix (Applied Biosystems, Foster City, CA, USA). Primers were designed to amplify 73 and $51 \mathrm{bp}$ fragments for YHR and $18 \mathrm{~S}$ rRNA, respectively. Standard curves were made by a dilution series of a reference sample, and expression levels were determined relative to the dilution utilized. A ratio of YHR/18S rRNA was calculated and normalized to the lowest level to obtain relative expression levels. Melting curve analysis was performed to ensure that no primer-dimer amplification was occurring.

\section{Measurements of hormone levels}

Blood was collected by cardiac puncture following asphyxiation with $\mathrm{CO}_{2}$, and serum was collected by centrifugation. Serum testosterone concentrations from male mice were measured by coat-a-count RIA (Diagnostics Products Corporation, Los Angeles, CA, USA) with a sensitivity of $0.2 \mathrm{ng} / \mathrm{ml}$; intraassay coefficient of variation (CV) was $10 \cdot 3 \%$ at $0.2 \mathrm{ng} / \mathrm{ml}$ and $1 \%$ at $4 \mathrm{ng} / \mathrm{ml}$. Testicular testosterone was measured by RIA (Pantex, Santa Monica, CA, USA) following extraction of testicular homogenates with diethyl ether. One (8 and 12 weeks) or two (3 and 5 weeks) testes were first homogenized in $5 \mathrm{ml}$ PBS using a Polytron homogenizer (Tekmar Company, Cincinnati, OH, USA) and then extracted three times with $5 \mathrm{ml}$ diethyl ether. Testicular testosterone levels are expressed as the total amount in both testes. The limit of sensitivity was $0 \cdot 1 \mathrm{ng} / \mathrm{ml}$ and the intra-assay CV was $10 \cdot 5 \%$. Ovarian estradiol and testosterone were measured following extraction of the ovaries with diethyl ether.

Both ovaries were homogenized in $0.5 \mathrm{ml}$ PBS and extracted three times with $2 \mathrm{ml}$ diethyl ether. The ovarian estradiol and testosterone concentrations were measured utilizing ELISA kits from Neogen (Lexington, KY, USA) following manufacturer's instructions. The sensitivities of the assays were $20 \mathrm{pg} / \mathrm{ml}$ and $2 \mathrm{pg} / \mathrm{ml}$ for estradiol and testosterone, respectively. Serum levels of progesterone from female mice were determined by RIA (Diagnostics Products Corporation, Los Angeles, CA, USA) with a sensitivity limit of $0 \cdot 1 \mathrm{ng} / \mathrm{ml}$ and intraassay CV of $6 \cdot 1 \%$ at $0 \cdot 1 \mathrm{ng} / \mathrm{ml}$ and $4 \cdot 8 \%$ at $2 \mathrm{ng} / \mathrm{ml}$. Serum $\mathrm{LH}$ and FSH levels were measured utilizing mouse standards and antiserum (AFP5306A standard/rLH-S1 1 antiserum for LH and AFP5308D standard/mFSH AFP-1760191 antiserum for FSH) purchased from Dr A 
Parlow of the NIDDK National Hormone and Peptide Program. Rat LH and FSH were iodinated by iodogen, and the antibody-antigen complexes in the RIA were precipitated with the antibody precipitating system from Linco Research (St Charles, MO, USA). The sensitivity of the LH assay was $0 \cdot 1 \mathrm{ng} / \mathrm{ml}$ and intraassay $\mathrm{CV}$ of $18 \%$ at $0 \cdot 1 \mathrm{ng} / \mathrm{ml}$ and $7 \cdot 8 \%$ at $0 \cdot 8 \mathrm{ng} / \mathrm{ml}$.
The sensitivity of the FSH assay was $0.8 \mathrm{ng} / \mathrm{ml}$; the intraassay CV was $16 \%$ at $0.8 \mathrm{ng} / \mathrm{ml}$ and $5 \%$ at $25 \mathrm{ng} / \mathrm{ml}$. Measurements of hormone levels from 12-week-old female mice were from randomly cycling animals. Serum hormone measurements were performed in single aliquots. Testicular and ovarian steroid hormone measurements were performed in duplicate.

A

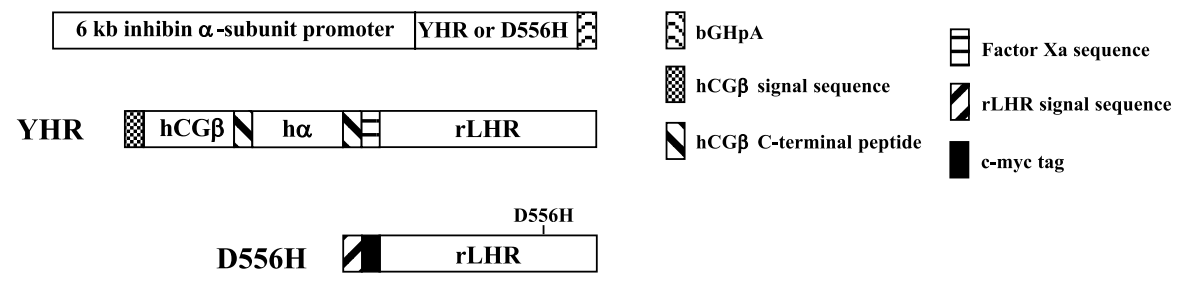

B

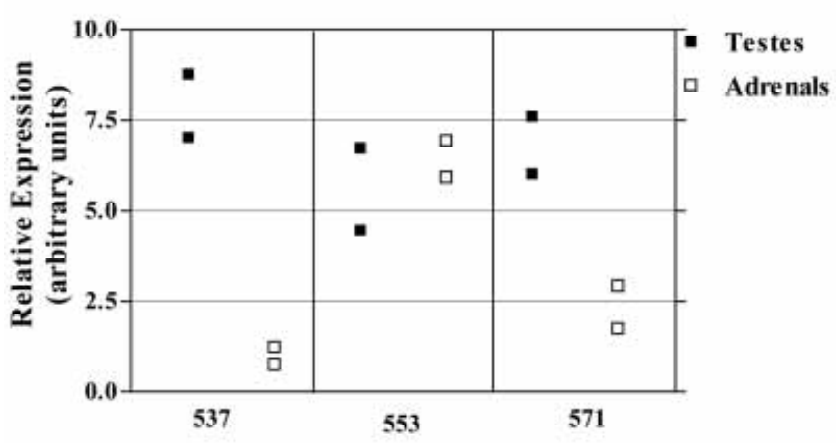

D

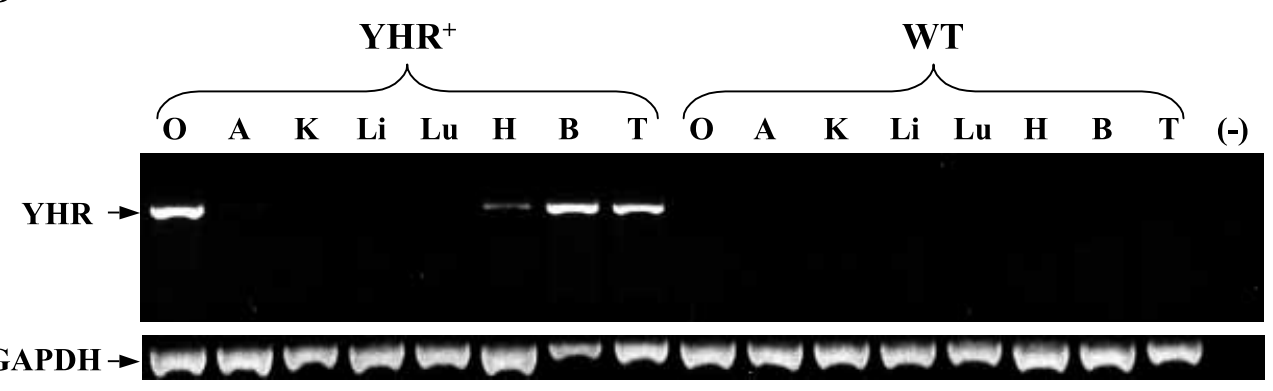

C

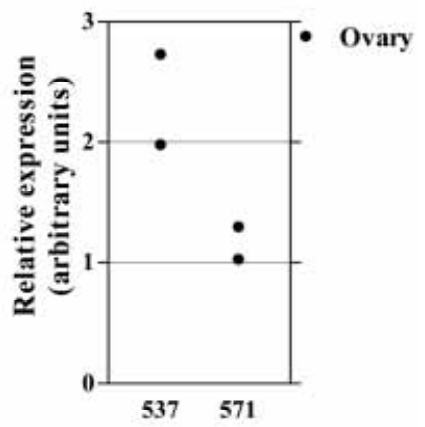

$\mathbf{E}$

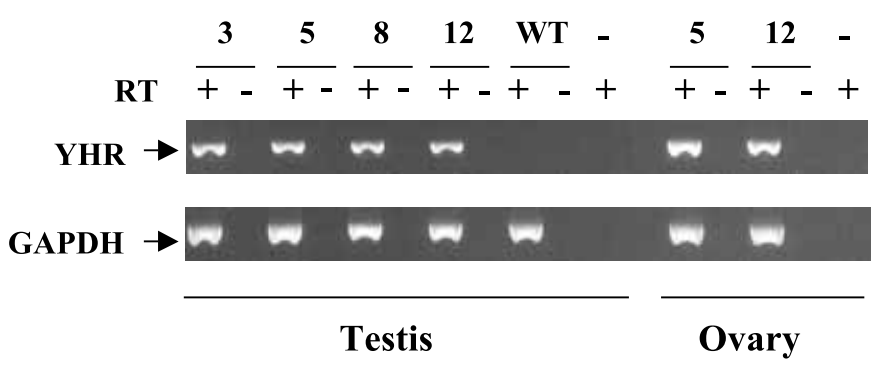




\section{Histology and immunohistochemistry}

Tissues were fixed in 10\% buffered formalin and embedded in paraffin. Serial sections $(5 \mu \mathrm{m})$ were stained with hematoxylin and eosin prior to histological examination by light microscopy. Staining of Leydig cells was accomplished by immunohistochemistry with an antibody to $3 \beta$ hydroxysteroid dehydrogenaseI (3ßHSDI, kindly provided by Dr Anita Payne, Stanford University, CA, USA). A 1/800 dilution of the antibody was used for staining utilizing Histostain Plus kit with DAB chromogen (Zymed Laboratories, Inc., South San Franscisco, CA, USA). Counterstaining was performed with hematoxylin.

The cross-sectional area of individual tubules was determined by digital image analysis of testicular sections from three animals per genotype and age. The cross-sectional area in pixels was measured from at least 100 independent tubules per animal per genotype using the NIH image J software package. A calibration standard was used to convert the pixel value to the cross-sectional area in $\mu \mathrm{m}^{2}$.

\section{Statistical analysis}

Control and transgenic animals at the same age were compared with the Mann-Whitney test using the Prism software program (GraphPad Software, Inc., San Diego, CA, USA). $P<0 \cdot 05$ was considered significant.

\section{Results}

\section{$\mathrm{YHR}^{+}$mice display gonadal expression}

Eight YHR founder mice were bred to establish lines. Three of the founders did not transmit the transgene, while the remaining five transmitted the transgene and four lines expressed the receptor in the testes and ovaries of N1 progeny as determined by RT-PCR (data not shown). Three of the four lines exhibited similar levels of testicular expression measured by semi-quantitative RTPCR performed on N1 progeny (Fig. 1B), and line 553 also showed higher adrenal expression. Later, real-time RT-PCR on RNA from the 2 lines with relatively lower adrenal expression (537 and 571) showed YHR expression in the ovaries as well (Fig. 1C). These two lines were chosen for further study of the effects of YHR expression in the gonads on reproductive function and development. Southern blot analysis on N1 progeny from the 537 and 571 lines determined a single integration site of the transgene and copy numbers of 4 and 10, respectively (data not shown). Transgenic mice derived from both lines presented with similar phenotypes and the data presented are from mice of the 571 line.

YHR expression was also determined in multiple tissues of 4-week-old mice from the 571 line by RT-PGR (Fig. 1D). In addition to the expected expression in the testes and ovaries, mRNA was also detected at high levels in the brain and at a lower level in the heart, consistent with previous reports of inhibin $\alpha$-subunit expression in these tissues (Roberts et al. 1991). Adrenal expression of YHR, which was apparent in mice of the $\mathrm{N} 1$ generation (Fig. 1B), was barely detectable in the mice from the N6 generation (Fig. 1D), suggesting that the genetic background of the mice influenced adrenal expression. There was no amplification of the endogenous mouse LHR sequence with primers specific for YHR as evidenced by lack of a specific band in RNA samples from wild type (WT) mice. Controls without reverse transcriptase also did not reveal any amplification of contaminating DNA (data not shown). Finally, expression of YHR at pre-and post-pubertal ages was confirmed by RT-PCR (Fig. 1E). Specific YHR expression was detected in testis from transgenic mice at 3, 5, 8, and 12 weeks of age and from ovaries at 5 and 12 weeks of age.

\section{Prepubertal elevation in testosterone levels in $\mathrm{YHR}^{+}$ male mice}

In order to determine if YHR expression affects testosterone production, levels of testosterone were measured in serum and in testicular extracts. Serum testosterone levels were significantly increased as early as

Figure 1 Expression of YHR mRNA in transgenic mice. (A) Schematic of transgenic constructs. YHR and D556H myc-rLHR were cloned under the control of the $6 \mathrm{~kb}$ mouse inhibin $\alpha$-subunit promoter in pBS-SK (-) with a bovine growth hormone polyadenylation signal (bGHpA). YHR consists of hCG $\beta$-subunit with its signal sequence linked to the human $\alpha$-subunit via the hCG $\beta$ C-terminal peptide (CTP), which in turn is linked to the extracellular domain of the LHR by an additional CTP and a Factor Xa recognition sequence. D556H myc-rLHR is preceded by the signal sequence for LHR and a ten amino acid human c-myc tag. (B) Relative expression in N1 progeny from multiple YHR lines as determined by semi-quantitative RT-PCR. YHR expression in the testes and adrenals is given as a ratio to $18 \mathrm{~S}$ rRNA signal as an internal standard and normalized to the lowest expression level. Individual values from two determinations are shown. (C) Real-time RT-PCR of RNA from ovaries of the 537 and 571 lines. YHR expression is given as a ratio to $18 \mathrm{~S}$ rRNA and normalized to the lowest expression level. The values obtained from two individual samples are shown. (D) YHR expression in multiple tissues of $\mathrm{YHR}^{+}$and wild type (WT) mice. RNA from the non-gonadal tissues was prepared from female mice. O, ovary; A, adrenal; K, kidney; Li, liver; Lu, lung; H, heart; B, brain; T, testes; (-), template-free control. (E) YHR expression in testis of $\mathrm{YHR}^{+}$mice at 3, 5, 8 and 12 weeks of age and in ovaries from 5- and 12-week-old YHR ${ }^{+}$mice. cDNA was synthesized in the presence (+) or absence (-) of reverse transcriptase (RT). Reactions with testicular RNA from an 8-week-old WT mouse and without template (-) were performed to ensure specificity of amplification. GAPDH primers were utilized as a positive control for RNA quality. 
A

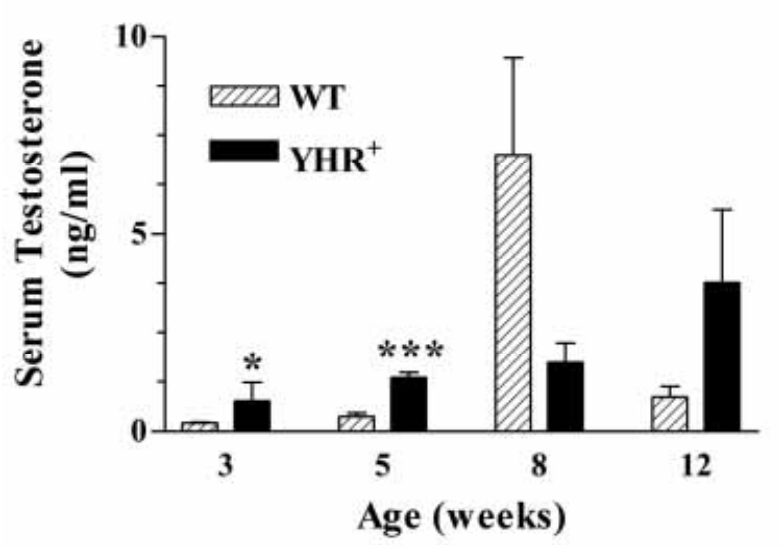

B

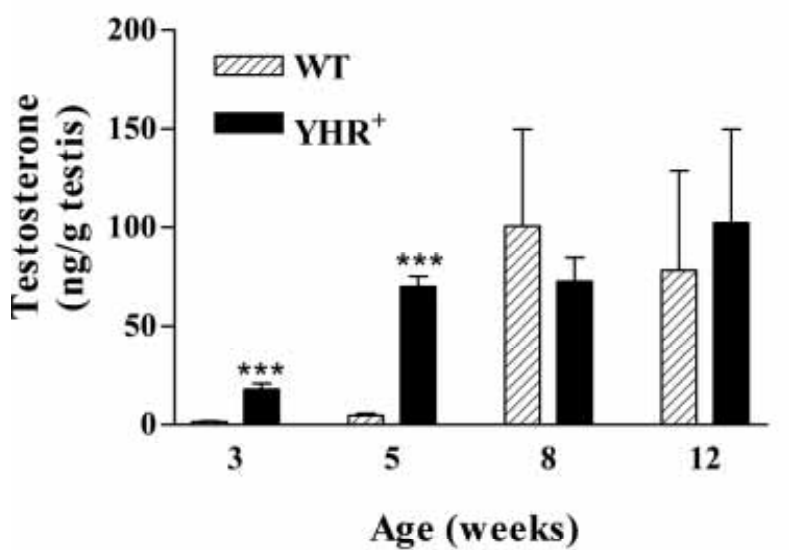

\section{C}

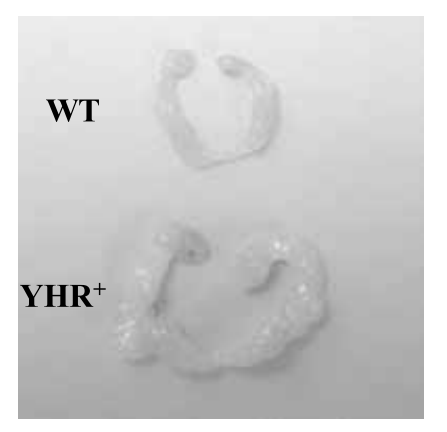

D

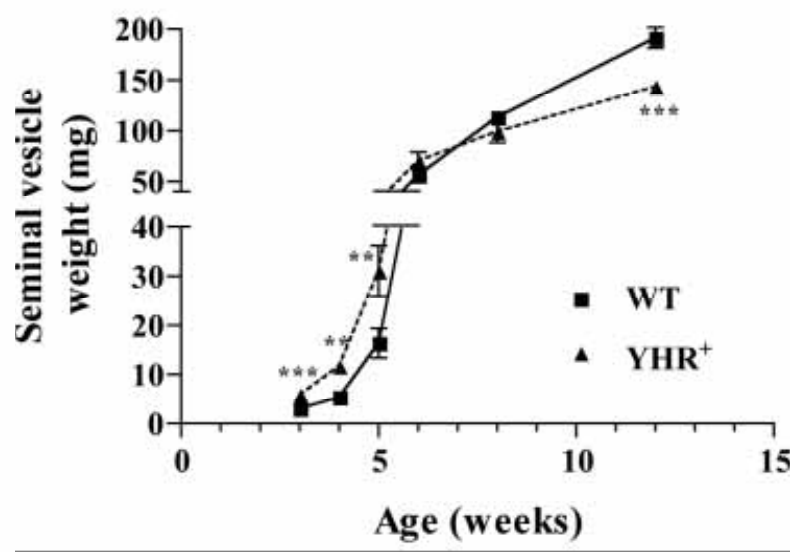

Figure 2 Testosterone levels and seminal vesicle weights in transgenic mice. Testosterone was determined in serum (A) and in testicular extracts (B) by RIA. Most of the serum testosterone levels at 3 weeks of age in the WT animals were below the standard curve and were assigned the value of the lowest standard $(0.2 \mathrm{ng} / \mathrm{ml})$ for graphing purposes. Testicular testosterone (B) is the total amount per gram testes. $n=6-11$ for data presented in panels $A$ and $B$. (C) Seminal vesicles of $Y_{H R}^{+}$and WT mice at 5 weeks of age. (D) Seminal vesicle weights in animals 3-12 weeks of age. $n=4-11$. Data in panels A, B and D represent means \pm S.E.M. ${ }^{*} P<0.05 ;{ }^{\star \star} P<0.01 ;{ }^{* \star *} P<0.001$ compared with WT.

3 and 5 weeks of age in $\mathrm{YHR}^{+}$mice (Fig. 2A). At older ages ( 8 and 12 weeks of age), the serum testosterone levels were not significantly different. Testicular testosterone levels (Fig. 2B) exhibited the same pattern as the serum levels with significant increases at 3 and 5 weeks of age over non-transgenic littermates. At 8 and 12 weeks of age, there was no difference in testicular testosterone of $\mathrm{WT}$ and $\mathrm{YHR}^{+}$animals.

Consistent with the increase in testosterone synthesis, the size of the seminal vesicles (Fig. $2 \mathrm{C}$ and $\mathrm{D}$ ) is dramatically increased in $\mathrm{YHR}^{+}$mice. Most significantly, increases in seminal vesicle weight occur at 3 (1.9-fold, $n=9-10), 4(2 \cdot 2$-fold, $n=4-5)$, and 5 weeks of age (1.9-fold, $n=10)$. These results reflect the increase in testosterone synthesis that occurs at prepubertal ages. There are no significant differences in seminal vesicle weight at 6 and 8 weeks of age. However, by 12 weeks of age, seminal vesicles of $\mathrm{YHR}^{+}$mice are significantly decreased in weight $(1 \cdot 3$-fold reduction, $n=6-8)$.

\section{YHR expression suppresses serum gonadotropin levels in male mice}

As might be expected with an increase in steroidogenesis, gonadotropin hormone levels were decreased in 


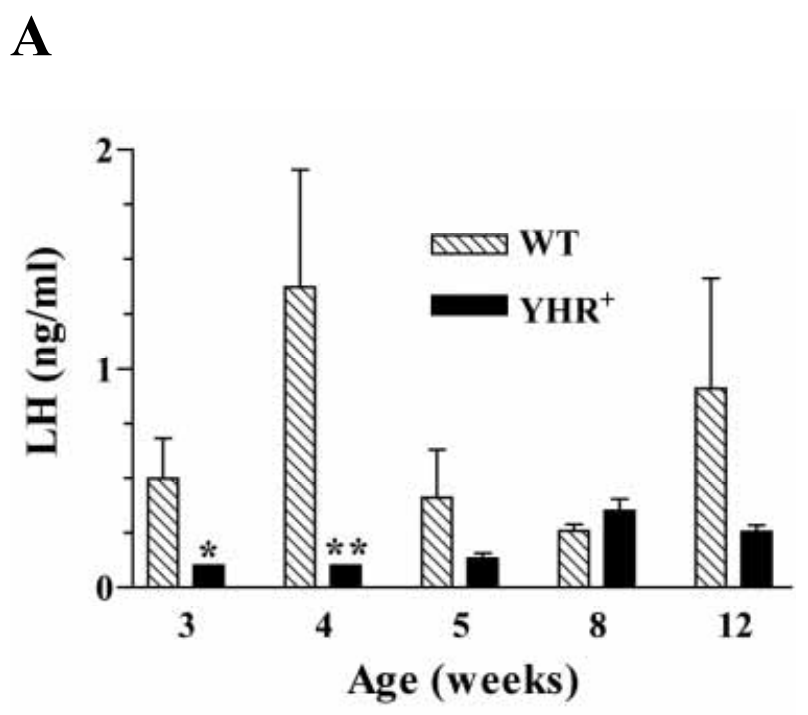

B

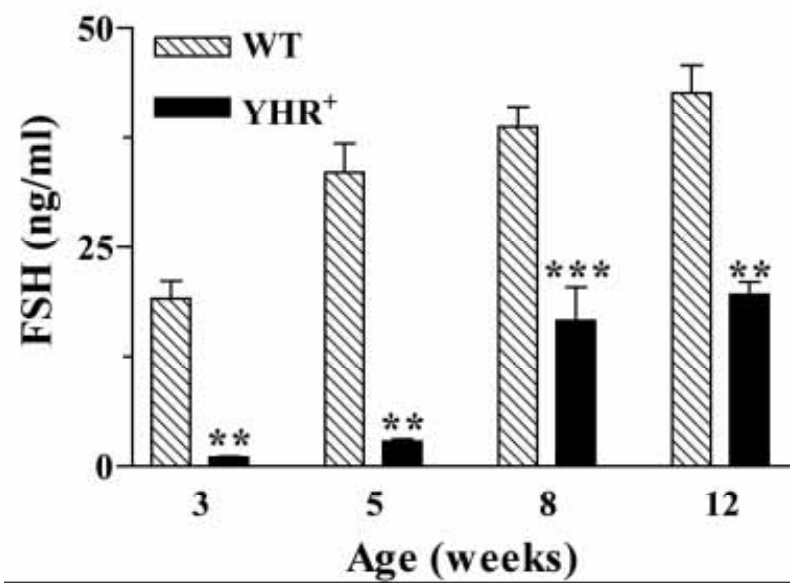

Figure 3 Serum LH and FSH levels in male $\mathrm{YHR}^{+}$and WT mice. $\mathrm{LH}(\mathrm{A})$ and $\mathrm{FSH}(\mathrm{B})$ levels were determined by RIA of serum samples and are presented as means \pm S.E.M. LH values from all 3- and 4-week-old $\mathrm{YHR}^{+}$mice were below the standard curve and were assigned the value of the lowest standard $(0.1 \mathrm{ng} / \mathrm{ml})$ for graphing purposes. $n=4-10 ;{ }^{\star} P<0.05$; ${ }^{\star \star} P<0.01 ;{ }^{* \star \star} P<0.001$ compared with WT.

$\mathrm{YHR}^{+}$mice. Serum LH levels were significantly reduced in 3- and 4-week-old $\mathrm{YHR}^{+}$mice, but not in 5-, 8-, and 12-week-old animals (Fig. 3A). In contrast to LH levels, serum FSH levels were significantly decreased in $\mathrm{YHR}^{+}$ mice at all ages (Fig. 3B). At 3 and 5 weeks of age, FSH levels were reduced approximately 19 -fold $(n=5-6)$ and 12 -fold $(n=6)$, respectively. At older ages, the decrease in
FSH was not as severe with an approximate 2-fold reduction at $8(n=6-8)$ and $12(n=6)$ weeks of age.

\section{YHR expression affects testicular development}

$\mathrm{YHR}^{+}$mice exhibited a significant decrease in testes size at 3-12 weeks of age (Fig. 4A and B). The decrease in weight is most severe at 6 weeks of age $(54 \%$ reduced, $n=10)$, but is apparent by 3 weeks of age (35\% reduced, $n=9-10)$. At later ages, the effects on testes development are reduced, however, the testicular weights in $\mathrm{YHR}^{+}$mice are still significantly reduced at 8 weeks $(40 \%$ reduced, $n=9-10)$ and 12 weeks $(22 \%$ reduced, $n=6-8$ ).

Histological analysis of the testes demonstrated that the reduction in testicular weight of $\mathrm{YHR}^{+}$mice is manifested by an apparent reduction in the tubule size that is evident at 5 weeks of age (Fig. 4C). Other than the overall size of the tubules, there are no clear differences in the histology of the tubules at the light microscope level. Spermatids are not detected in testicular sections of 3-week-old $\mathrm{YHR}^{+}$mice indicating that spermatogenesis is not initiated earlier in these mice. A qualitative analysis of hematoxylin and eosin stained sections also did not reveal any changes in the volume of the interstitium or Leydig cell morphology. Immunohistochemistry with $3 \beta \mathrm{HSDI}$ antiserum to specifically stain the Leydig cells further confirmed this observation (Fig. 4C). To confirm the observed reduction in tubule size, a quantitative analysis of the cross-sectional area of the tubules at the various ages was performed. Testis sections from three mice per genotype and age were analyzed and the area of 100 independent tubules from each animal was measured. The analysis showed that the tubules from the transgenic mice at 3-12 weeks of age were significantly smaller than WT littermates (Fig. 4D), consistent with the decrease in testicular size.

\section{$\mathrm{YHR}^{+}$female mice undergo precocious puberty}

$\mathrm{YHR}^{+}$mice exhibited precocious puberty as evidenced by the premature vaginal opening that occurred at 23.5 days $(n=8)$ as compared with WT controls at $31 \cdot 3$ days $(n=9) \quad(P<0 \cdot 001)$. In addition, there was a 10 -fold increase in the size of the uterus at 5 weeks of age (Fig. $5 \mathrm{~A}$, Table 1). The non-transgenic mice had thin, atrophic uteri, compared with the enlarged YHR uteri. This precocious development is readily visualized in the uterine sections that show a marked dilation of the lumen (Fig. 5B vs 5C). The endometrial cells lining the lumen are hypertrophic (Fig. 5D vs 5E) and the stroma is edematous. These changes in the $\mathrm{YHR}^{+}$uterus are consistent with the trophic effects of estrogen.

The ovaries of 5-week-old $\mathrm{YHR}^{+}$mice exhibit increased folliculogenesis with a larger number of 

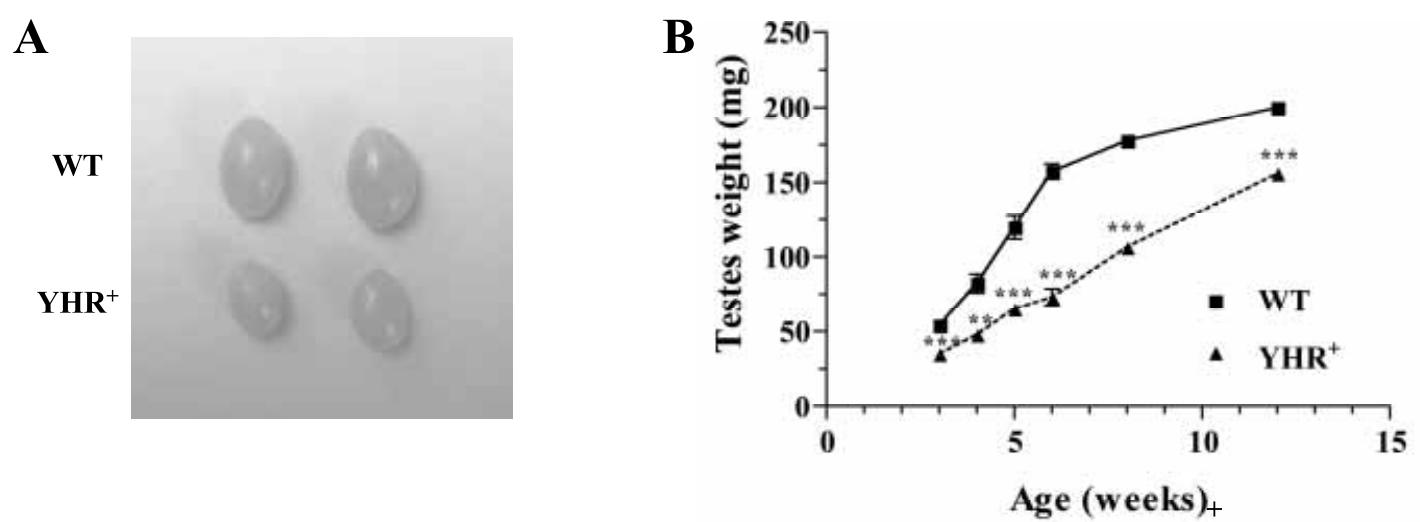

C
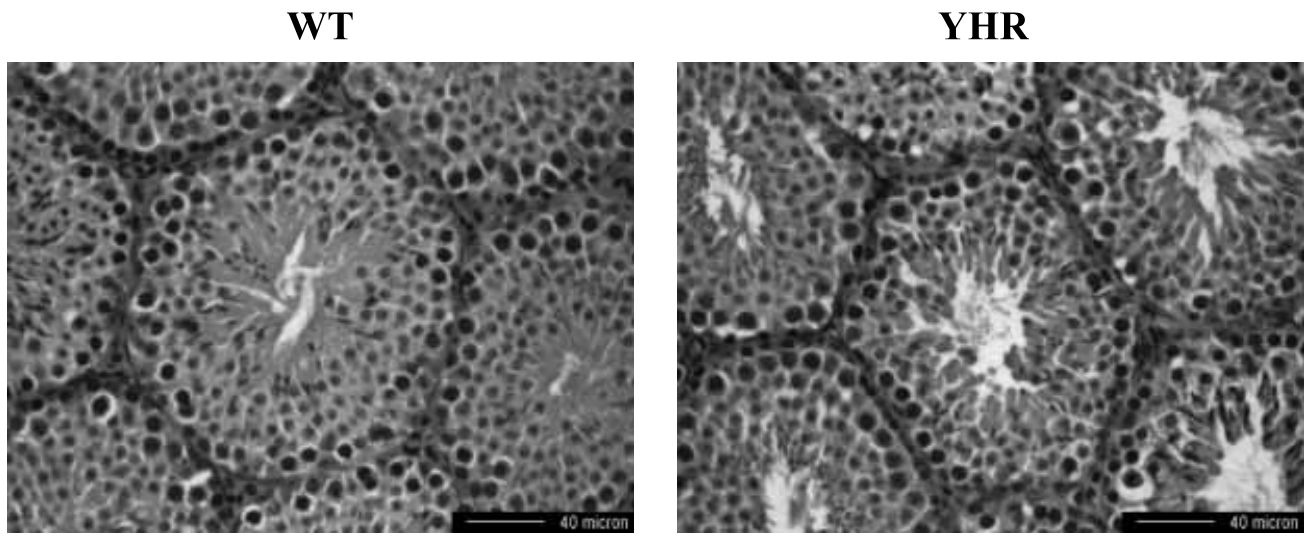

H\&E
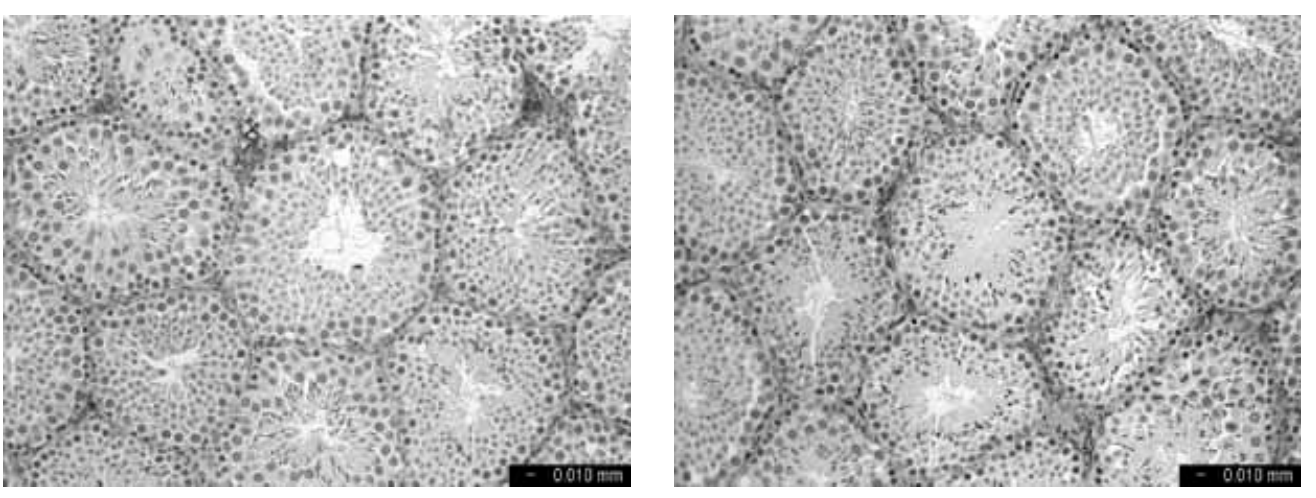

D

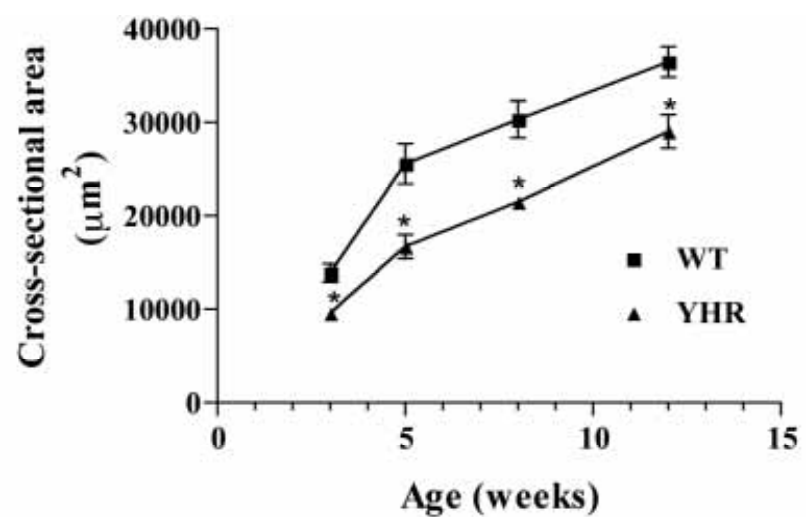


follicles at later stages of development, including the presence of CLs which are absent in WT controls at this age (Fig. 6A vs 6B). Many of these CLs in $\mathrm{YHR}^{+}$mice retain the oocyte (Fig. $6 \mathrm{C}$ ), indicating luteinization of the granulosa cells in the absence of ovulation. It is important to note, however, that the theca and granulosa cells of developing follicles appear unchanged (data not shown).

\section{Enhanced steroidogenesis in $\mathrm{YHR}^{+}$female mice}

To determine the effect of premature LHR activation on ovarian steroidogenesis, hormone levels were measured (Table 1). Ovarian estradiol $\left(\mathrm{E}_{2}\right)$ was increased $2 \cdot 7$-fold in $\mathrm{YHR}^{+}$mice, consistent with the precocious uterine enlargement. Ovarian testosterone (T) was not affected in $\mathrm{YHR}^{+}$mice; however, the $\mathrm{T} / \mathrm{E}_{2}$ ratio was significantly decreased, suggesting a higher level of aromatization of androgens in these mice. Serum progesterone levels were significantly elevated compared with control animals, consistent with the luteinization observed in the ovaries of $\mathrm{YHR}^{+}$mice. Serum LH and FSH were also decreased in 5-week-old mice indicating a functional hypothalamic-pituitary-gonadal (HPG) axis.

\section{Adult $\mathrm{YHR}^{+}$female mice exhibit degenerative changes in the ovary}

$\mathrm{YHR}^{+}$female mice were subfertile and produced litters sporadically with some females never producing litters. At 12 weeks of age, ovaries from $\mathrm{YHR}^{+}$mice contained cysts and an increase in the amount of intersititial tissue that appears disorganized and luteinized (Fig. 7A vs 7B). Although follicles at various stages of growth were still evident in these ovaries, they were mostly at the periphery. The theca and granulosa cells of the follicles appear normal. $\mathrm{YHR}^{+}$mice contain many small follicles with degenerative ova interspersed in the interstitium, and there is an overall increase in the number of atretic follicles (Fig. 7G vs 7D). Extensive interstitial cell hypertrophy characterized by vacuolated cytoplasm was evident. About $25 \%$ of $\mathrm{YHR}^{+}$mice developed hemorrhagic cysts (Fig. 7B) which can be observed as early as 5 weeks of age. Some of the cysts contain what appear to be normal granulosa cells, while others are surrounded by luteinized cells. In contrast, ovaries from age-matched controls contain all stages of follicle development, including CLs. Many of the morphological changes seen in the ovaries of 12-week-old mice are similar to those found in mice over one year of age.

At 12 weeks of age, steroid hormone and gonadotropin levels of randomly cycling mice were not significantly altered between $\mathrm{WT}$ and $\mathrm{YHR}^{+}$mice, and their average uterine weights were similar (Table 1). Histological analysis of the uterus revealed no major differences in the uterus from $\mathrm{WT}$ and $\mathrm{YHR}^{+}$mice (Fig. 8A vs 8B) or in the morphology of the endometrial cells and endometrial stroma (Fig. 8G vs 8D). The development of the endometrial glands was similar.

Occasionally, a grossly enlarged uterus, with as much as a 10-fold increase in weight, was observed in $\mathrm{YHR}^{+}$ mice (Fig. 8E). These uteri have a markedly distended fluid-filled lumen (hydrometria) with attenuated myometrium and endometrial stroma containing few endometrial glands (Fig. 8F). The ovaries of these mice had multiple large hemorrhagic cysts that are readily apparent on gross dissection. These individual mice exhibit periods of prolonged estrus and their ovarian estradiol and testosterone levels (data not shown) were elevated compared with $\mathrm{YHR}^{+}$mice with a normal uterus.

\section{Discussion}

The results presented herein describe, for the first time, the effects of expression of a constitutively active hCG-LHR complex in transgenic mice. The increase in testosterone in $\mathrm{YHR}^{+}$mice at the prepubertal ages of $3-5$ weeks is accompanied by an increase in the weights of the seminal vesicles. This increase is reflective of the well-established role of testosterone on seminal vesicle growth and differentiation (Higgins et al. 1976, Gonzales 2001). Interestingly, the dramatic differences in testosterone levels between $\mathrm{WT}$ and $\mathrm{YHR}^{+}$mice observed at prepubertal ages (3 and 5 weeks) are not apparent at adult ages (8 and 12 weeks) even though YHR expression can be detected in the testis at these ages (Fig. 1E). A recent report (Shinozaki et al. 2003) has demonstrated that a constitutively active LHR, when co-transfected with WT receptor into HEK 293 cells, causes an attenuation of ligandmediated cAMP production. Since the $\mathrm{YHR}^{+}$mice are heterozygous and express both WT LHR and YHR, the LH-mediated testosterone response of WT LHR in these mice at 8 and 12 weeks of age could be reduced resulting in similar levels of testosterone in WT and $\mathrm{YHR}^{+}$mice.

\footnotetext{
Figure 4 Effects of $\mathrm{YHR}^{+}$expression on testicular development. (A) Testes in 5-week-old $\mathrm{YHR}^{+}$mice compared with a non-transgenic littermate (WT). (B) Testes weights in animals from 3-12 weeks of age. $n=4-10$. (C) Photomicrographs comparing testicular sections of 5-week-old control and $\mathrm{YHR}^{+}$mice. Sections were stained with hematoxylin-eosin (H\&E) or immunostained with antiserum to $3 \beta \mathrm{HSDI}$ to specifically stain Leydig cells. (D) Average cross-sectional area of seminiferous tubules in testis from 3-12-week-old mice. $n=3$. Data in panels $B$ and $D$ represent means \pm S.E.M. ${ }^{\star} P<0.05,{ }^{\star \star} P<0.01 ;{ }^{\star * \star} P<0.001$ compared with WT.
} 

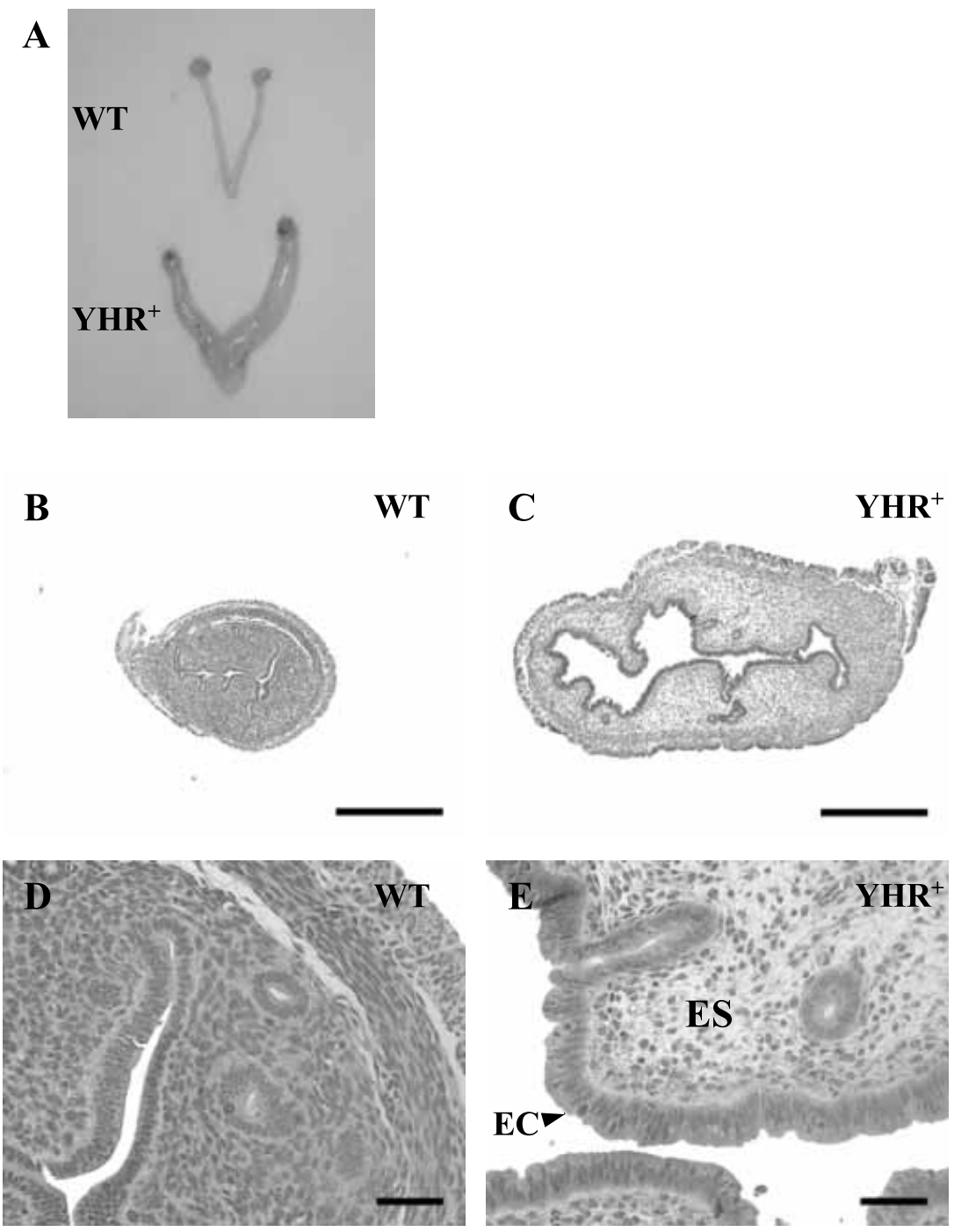

Figure 5 Uterus from $\mathrm{YHR}^{+}$mice at 5 weeks of age. (A) Gross morphology of the uterus and ovaries of 5-week-old mice demonstrating precocious uterine development in $\mathrm{YHR}^{+}$mice. (B and $\mathrm{C}$ ) Photomicrographs of a cross-section of the uterine horn of a WT and $\mathrm{YHR}^{+}$mouse. Note the large increase in uterine size and the dilated lumen in the $\mathrm{YHR}^{+}$mouse. (D) Higher magnification of the WT uterus showing the endometrial epithelial cells (EC) and endometrial stroma (ES). (E) Higher magnification of the $\mathrm{YHR}^{+}$uterus showing the hypertrophy of the EC and edema of the ES, consistent with the trophic effects of estrogen. Scale bars represent $0.5 \mathrm{~mm}(B, C)$ and $50 \mu \mathrm{m}(D, E)$.

The expression of YHR in prepubertal transgenic mice results in a decrease in serum gonadotropin levels concomitant with an increase in testosterone synthesis. This effect is most likely due to the feedback inhibition of testosterone on the synthesis and secretion of $\mathrm{LH}$ from the pituitary and suggests that the HPG axis is functional in mice at these early ages (Huhtaniemi 1995). In contrast to $\mathrm{LH}, \mathrm{FSH}$ levels remain decreased in $\mathrm{YHR}^{+}$ mice at 8 and 12 weeks of age when testosterone levels are not different between $\mathrm{WT}$ and $\mathrm{YHR}^{+}$mice. The reason for this is not clear but our results suggest a difference in the regulation of the synthesis and secretion of $\mathrm{FSH}$ in $\mathrm{YHR}^{+}$mice compared to WT mice. A similar observation was recently reported in male transgenic mice expressing hCGB (Rulli et al. 2003).

The decrease in testicular size and area of seminiferous tubules in prepubertal and adult $\mathrm{YHR}^{+}$ mice is presumably due to the decreased levels of FSH. The importance of FSH in testicular development has been established in knockout mouse models of FSH $\beta$ and FSH receptor (Kumar et al. 1997, Dierich et al. 1998). Additionally, expression of FSH or a 
Table 1 Summary of steroid and gondaotropin hormone levels in female transgenic mice

\begin{tabular}{|c|c|c|c|c|c|c|c|}
\hline & $\begin{array}{l}\text { Estradiol }\left(E_{2}\right) \\
(p g)^{1}\end{array}$ & $\begin{array}{l}\text { Testosterone (T) } \\
(\mathrm{pg})^{1}\end{array}$ & $\mathrm{~T} / \mathrm{E}_{2}$ Ratio & $\begin{array}{l}\text { Progesterone } \\
(\mathrm{ng} / \mathrm{ml})^{2}\end{array}$ & LH $(\mathrm{ng} / \mathrm{ml})^{2}$ & FSH $(\mathrm{ng} / \mathrm{ml})^{2}$ & Uterus (mg) \\
\hline $\begin{array}{l}5 \text { week-old } \\
\text { WT } \\
\mathrm{YHR}^{+}\end{array}$ & $\begin{array}{l}32 \pm 4(8) \\
85 \pm 29(7)^{a}\end{array}$ & $\begin{array}{l}90 \pm 13(8) \\
91 \pm 19(7)\end{array}$ & $\begin{array}{l}2 \cdot 8 \pm 0.2(8) \\
1.5 \pm 0.4(7)^{b}\end{array}$ & $\begin{array}{l}0.36 \pm 0.02(5) \\
1.47 \pm 0.32(5)^{\mathrm{b}}\end{array}$ & $\begin{array}{l}0.18 \pm 0.03(6) \\
<0.10(6)^{a}\end{array}$ & $\begin{array}{l}9.35 \pm 0.78(6) \\
6.54 \pm 0.97(6)^{a}\end{array}$ & $\begin{array}{c}20 \pm 4(9) \\
192 \pm 68(10)^{c}\end{array}$ \\
\hline $\begin{array}{l}12 \text { week-old } \\
\text { WT } \\
\mathrm{YHR}^{+}\end{array}$ & $\begin{array}{r}74 \pm 27(7) \\
134 \pm 70(7)\end{array}$ & $\begin{array}{r}39 \pm 14(7) \\
105 \pm 51(7)\end{array}$ & $\begin{array}{l}0.6 \pm 0.1(7) \\
1.1 \pm 0.3(7)\end{array}$ & $\begin{array}{l}1.26 \pm 0.57(5) \\
1.96 \pm 0.48\end{array}$ & $\begin{array}{l}0.43 \pm 0.15(6) \\
0.23 \pm 0.03(6)\end{array}$ & $\begin{array}{r}8 \cdot 27 \pm 2.90(6) \\
12.43 \pm 4.63(6)\end{array}$ & $\begin{array}{c}81 \pm 7(7) \\
373 \pm 207(9)^{d}\end{array}$ \\
\hline
\end{tabular}

Data are mean \pm S.E.M. $(n)$.

${ }^{1}$ Values represent total amount of hormone $(\mathrm{pg})$ from both ovaries.

${ }^{2}$ Progesterone, $\mathrm{LH}$, and FSH were measured in serum.

aSignificantly different from wild type (WT) controls, $P<0.05$.

bSignificantly different from WT controls, $P<0.01$.

cSignificanlty different from WT controls, $P<0.001$.

dIncludes uteri with hydrometria.

constitutively active FSH receptor on the gonadotropindeficient hypogonadal $(h p g)$ mouse background, which exhibits reduced testis size, results in an increase in testicular weight (Allan et al. 2001, Haywood et al. 2002), demonstrating a direct role for FSH in testicular development.
Several mutations in the transmembrane helices of LHR leading to constitutive receptor activation have been identified in males with gonadotropin-independent precocious puberty, a disorder characterized by prepubertal increases in testosterone and Leydig cell hyperplasia (Themmen \& Huhtaniemi 2000, Shenker
A

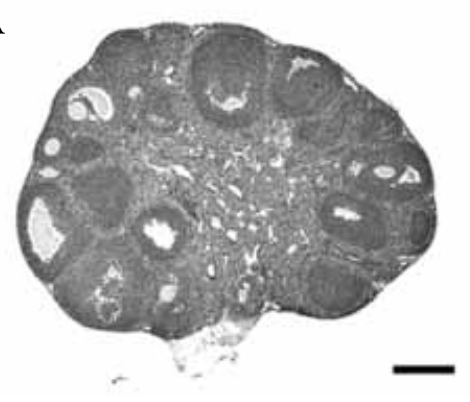

B

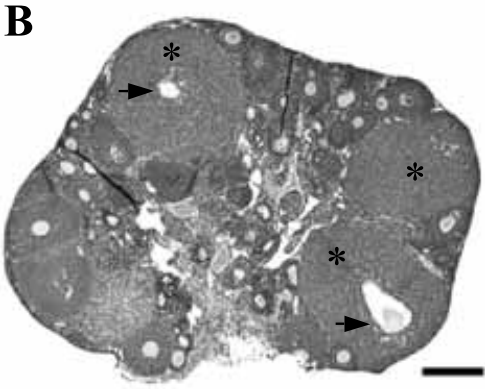

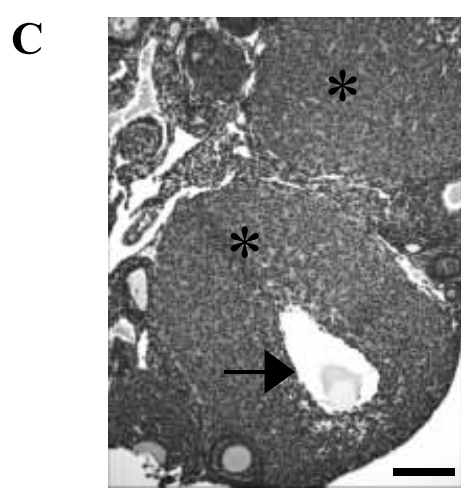

Figure 6 Photomicrographs of the ovary at 5 weeks of age. (A) WT ovary containing only limited follicular development with no follicles larger than the early antral stage and no corpora lutea. (B) $\mathrm{YHR}^{+}$ovary revealing increased follicular development including the presence of corpora lutea $\left({ }^{*}\right)$ with retained oocyte (arrow). (C) Higher magnification of the $\mathrm{YHR}^{+}$ovary. Note the presence of the oocyte in a corpus luteum. Scale bars represent $250 \mu \mathrm{m}(\mathrm{A}, \mathrm{B})$ and $100 \mu \mathrm{m}(\mathrm{C})$. 

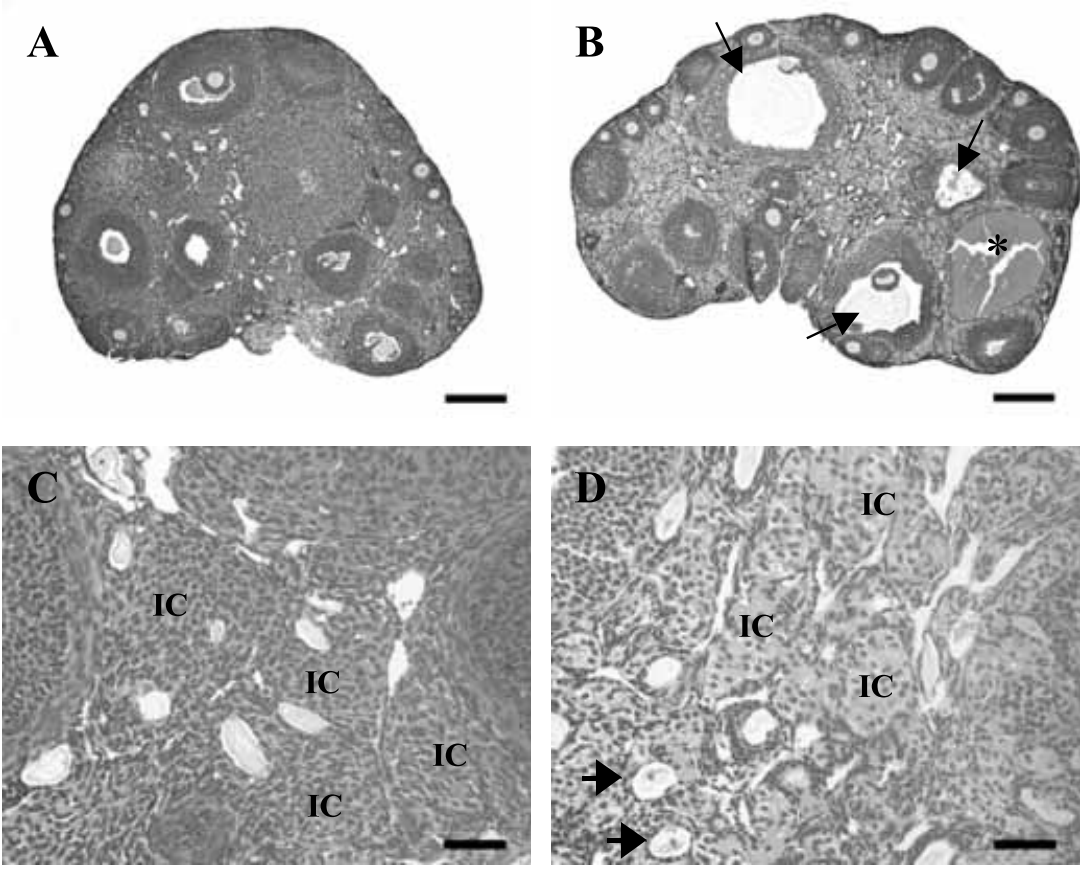

Figure 7 Photomicrograph of the ovary of 12-week-old mice. (A) WT ovary containing follicles at all stages of development, including the presence of a corpus luteum. (B) $\mathrm{YHR}^{+}$ovary demonstrating the presence of degenerating follicles developing into cysts (arrows), hemorrhagic cysts $\left(^{*}\right)$, and interstitial cell luteinization. (C) Higher magnification of WT ovary showing the interstitial tissue. (D) Higher magnification of the $\mathrm{YHR}^{+}$ovary showing interstitial cell (IC) hypertrophy containing small lipid-filled vacuoles and many follicles with degenerating ova (arrows). Scale bars represent $250 \mu \mathrm{m}(\mathrm{A}, \mathrm{B})$ and $50 \mu \mathrm{m}(\mathrm{C}, \mathrm{D})$.

2002). The activating mutations occur in both sporadic and familial male limited precocious puberty (FMPP) and are dominant over the wild type receptor. Whether Leydig cell hyperplasia in these patients is caused by the activation of the primary cAMP pathway or due to the activation of other pathways involved in cell proliferation remains to be determined. Except for the increase in levels of testosterone, the phenotype of male $\mathrm{YHR}^{+}$ mice is not similar to that of humans expressing a constitutively active LHR arising from mutations in the transmembrane helices. It is likely that expression of $\mathrm{YHR}^{+}$under the control of the inhibin $\alpha$-subunit promoter does not mimic the cell specific and temporal expression of the LHR. Attempts to detect cell-specific expression of YHR in the testes by immunohistochemistry using antisera specific for the GTP and hCG $\beta$ were not successful, perhaps due to limitations in the sensitivity of detection. Using published protocols (Amway et al. 2003), we have also attempted to purify Leydig and Sertoli cells from the testis of $\mathrm{YHR}^{+}$mice and test expression of YHR mRNA in these cells by RT-PCR. Although the isolation procedure yielded enriched populations of Leydig and Sertoli cells, they were not homogeneous as determined by RT-PCR using
Leydig (3ßHSDI) and Sertoli cell markers (FSHR and androgen binding protein).

Ectopic overexpression of hCG under the ubiquitin (Rulli et al. 2003) or metallothionein promoter (Matzuk et al 2003) also resulted in decreased testis size and elevated testosterone levels. In contrast to $\mathrm{YHR}^{+}$mice, hCG overexpressing mice were infertile with progressive degeneration of the tubules. Leydig cell hyperplasia was observed; however, the testosterone levels in adult mice older than 12 weeks of age were 4-5 fold higher than in $\mathrm{YHR}^{+}$mice. Furthermore, Rulli et al. (2003) showed that at 2-4 months of age the testes were normal and Leydig cell hypertrpohy was observed only at 6 months of age.

Female mice expressing constitutively active LHR exhibit a distinct ovarian phenotype. The prepubertal morphological and histological changes in the transgenic mice can be readily explained by the hormonal alterations that are induced by YHR expression in the ovaries. The precocious vaginal opening, e.g. 8 days prior to the WT control, and the appearance of a mature, enlarged uterus at 5 weeks of age are consistent with the elevated estrogen levels. The suppression in the levels of LH and FSH suggests that the estrogenmediated feedback of the HPG axis is fully functional 


\section{WT}
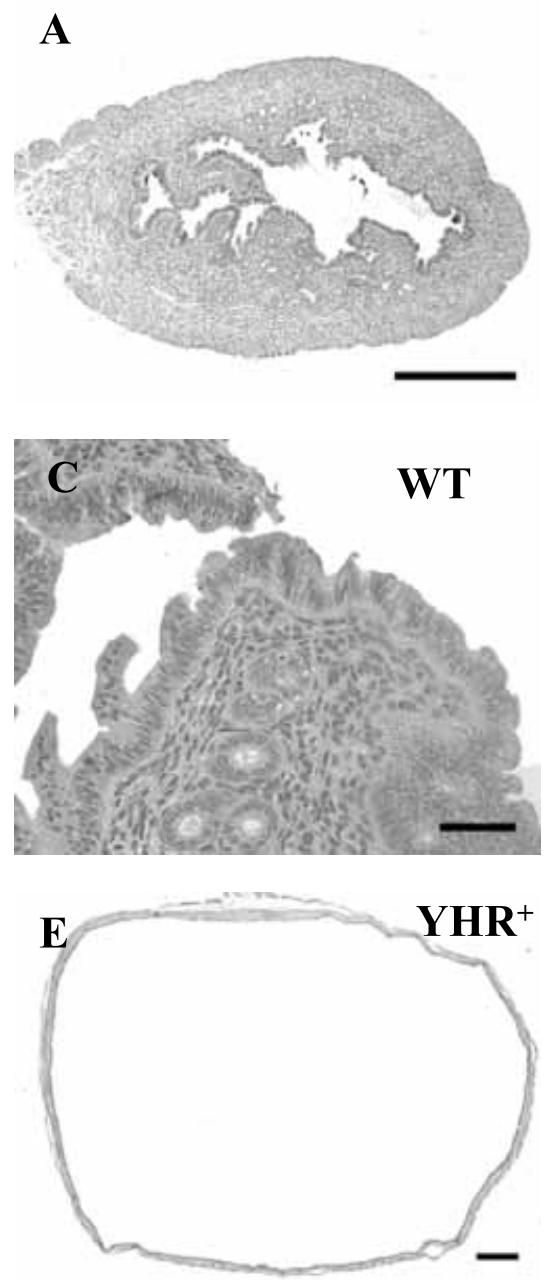
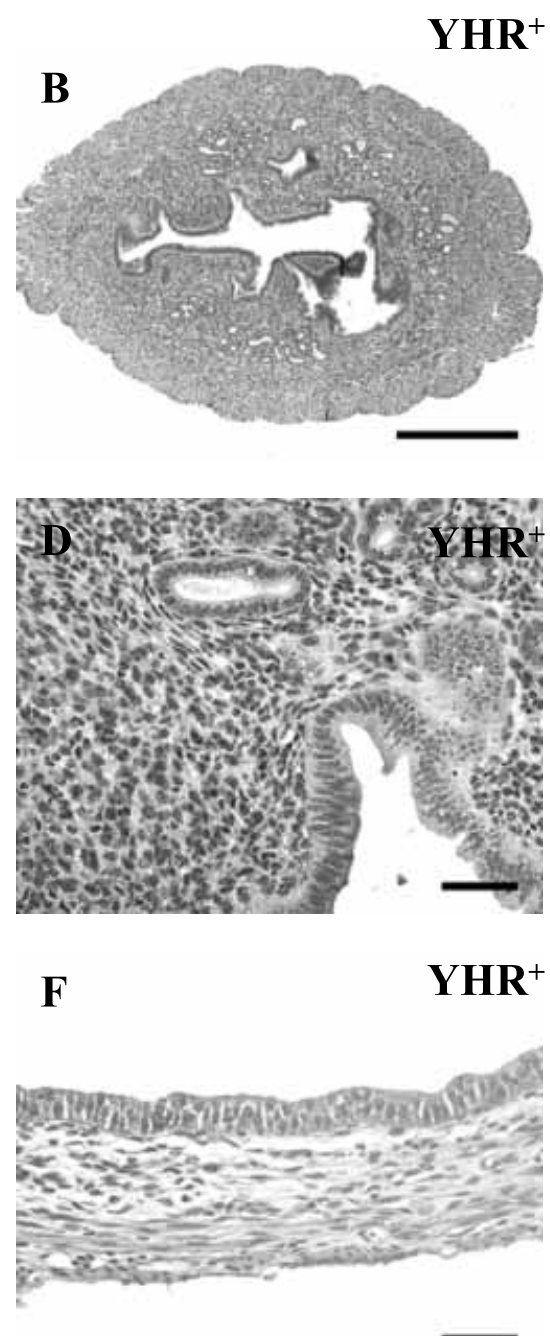

Figure 8 Photomicrographs of the uterus at 12 weeks of age. (A and B) WT and $\mathrm{YHR}^{+}$uterus demonstrating normal uterine development. (C and D) Higher magnification of the WT and $\mathrm{YHR}^{+}$uterus showing normal stromal and endometrial cell development. (E) $\mathrm{YHR}^{+}$uterus from an animal with a cystic ovary revealing a markedly dilated lumen that was filled with a clear fluid. (F) Higher magnification of $\mathrm{YHR}^{+}$uterus shown in panel $\mathrm{E}$. Note the attenuation of the endometrial stroma and myometrium due to uterine distension. Scale bars represent $0.5 \mathrm{~mm}(\mathrm{~A}, \mathrm{~B}, \mathrm{E})$ and $50 \mu \mathrm{m}(\mathrm{C}, \mathrm{D}, \mathrm{F})$.

(Huhtaniemi 1995) and that YHR expression is sufficient for accelerated follicular development and maturation. The presence of CLs, some with oocytes, and elevated levels of serum progesterone in the context of suppressed LH levels suggests that luteinization occurs in the absence of ovulation. Interestingly, the level of intraovarian testosterone is not elevated in YHR mice, suggesting that the conversion to estrogen is more efficient in $\mathrm{YHR}^{+}$ovaries. This result is in contrast with the model of the LH $\beta$-overexpressing mice, wherein hyperandrogenemia has been implicated in the development of precocious puberty, accelerated follicular development and cyst formation (Risma et al. 1995, 1997). The similarity in the ovarian phenotype between this model and the $\mathrm{YHR}^{+}$mice suggests that small increases in estrogen levels may be equally important in the development of ovarian lesions.

In addition to the LH $\beta$-overexpressing mice, two recent models (Rulli et al. 2002, Matzuk et al. 2003) of ectopic hCG $\beta$ overexpression exhibit reproductive disturbances similar to $\mathrm{YHR}^{+}$mice, including precocious puberty, infertility, massive luteinization and follicular cysts accompanied by prepubertal increases in estrogen, testosterone and progesterone. Unlike in 
$\mathrm{YHR}^{+}$mice, these hormonal imbalances persist into adulthood leading to a more severe phenotype including pituitary adenomas, mammary gland tumors and cystic kidneys. However, it is unclear if these extragonadal abnormalities are mediated by LHR since these mice produce supraphysiological levels of hCG (40-fold higher than normal LH levels) for as long as one year (Rulli et al. 2002). Although YHR expression is detected in adult mice, receptor desensitization may result in decreased YHR signaling. Nonetheless, the ovaries of $\mathrm{YHR}^{+}$mice develop interstitial cell luteinization and hypertrophy, increased follicular degeneration, and cysts suggesting that the early prepubertal increases in steroidogenesis may be sufficient for the development of early degenerative changes in the ovary.

Unlike the YHR mice, human female carriers of activating LHR mutations apparently fail to develop a distinct phenotype even though LHR is critical for female reproduction (Themmen \& Huhtaniemi 2000). However, current analysis of the female phenotype has been limited primarily to hormone analysis and the families investigated have mutations involving some of the milder FMPP phenotypes (Rosenthal et al. 1996, Ignacak et al. 2000, 2002). The relative increases in basal cAMP produced by most activating mutations found in FMPP patients (Shenker 2002) are smaller than those resulting from YHR, which has basal cAMP production approximately 25-fold higher than the wild-type receptor (Wu et al. 1996). Naturally occurring mutations in LHR that result in higher levels of constitutive activation have only been found in sporadic cases of precocious puberty (Laue et al. 1995, Muller et al. 1998) and in Leydig cell adenomas (Liu et al. 1999, Canto et al. 2001), with no reports to date in females. Also, many of these activated LHRs can still respond to the high doses of LH required for ovulation (Themmen \& Huhtaniemi 2000). Therefore, it is possible that if women harboring the more potent activating mutations are identified, they might exhibit the hormonal alterations and premature degenerative changes in the ovary seen in the $\mathrm{YHR}^{+}$ mouse model.

An unexpected finding in this study is the infertility exhibited by male and female D556H LHR (analogous to $\mathrm{D} 578 \mathrm{H}$ hLHR) transgenic founder mice which precluded the establishment of lines and a detailed characterization of their phenotype. Analysis of the major signal transduction pathways in cell culture demonstrated that both D556H LHR and YHR cause an increase in the basal levels of cAMP and IP (Wu et al. 1996, Liu et al. 1999, Angelova et al. 2002). However, since intracellular signaling is complex and can be context dependent, it is possible that the transgenes have disparate fertility phenotypes because their downstream signaling pathways are not precisely the same. It is worth noting that, to date, the $\mathrm{D} 578 \mathrm{H}$ mutation in humans has only been identified as a somatic mutation in Leydig cell adenomas (Liu et al. 1999), suggesting that this particular mutation is not compatible with germ-line transmission.

In summary, we have demonstrated that expression of a constitutively active YHR results in gonadal defects and a hormonal imbalance in both genders. The YHR ${ }^{+}$ mouse model can be utilized as a novel tool to explore the constitutively activated LHR signaling pathways on gonadal development. The accelerated folliculogenesis and early degenerative changes seen in the female mice suggest that the $\mathrm{YHR}^{+}$mice would be a good model to understand the molecular basis of premature ovarian failure.

\section{Acknowledgments}

This work was supported by NIH Research Grants DK33973 (DP) and HD 044119 (PN) and NIH Grants CA46592, AR20557, DK07367 and DK20572 supporting the University of Michigan Transgenic Core. We wish to thank Drs Mary Bedell and Aparna Mahakali Zama for their assistance with mouse procedures, Dr Joe Crim for his assistance with the radioiodination of $\mathrm{mLH}$ and mFSH, Ms Judy Gray for the genotyping of the mice utilized in this study, Dr Mark Farmer for assistance with the tubule measurements, Dr JoAnne Richards for helpful discussions and Dr Victor Olman for advice on the statistical analysis.

\section{References}

Allan CM, Haywood M, Swaraj S, Spaliviero J, Koch A, Jimenez M, Poutanen M, Levallet J, Huhtaniemi I, Illingworth P \& Handelsman DJ 2001 A novel transgenic model to characterize the specific effects of follicle-stimulating hormone on gonadal physiology in the absence of luteinizing hormone actions. Endocrinology 142 2213-2220.

Amway M, Folmer J, Wright W \& Zirkin B 2003 Isolation of Sertoli cells from Adult Rat Testes: An approach to ex vivo sutides of Sertoli cell function. Biology of Reproduction 68 996-1002.

Angelova K, Fanelli F \& Puett D 2002 A model for constitutive lutropin receptor activation based on molecular simulation and engineered mutations in transmembrane helices 6 and 7. Fournal of Biological Chemistry 277 32202-32213.

Ascoli M, Fanelli F \& Segaloff DL 2002 The lutropin/ choriogonadotropin receptor, a 2002 perspective. Endocrine Reviews 23 141-174.

Canto P, Soderlund D, Ramon G, Nishimura E \& Mendex JP 2001 Mutational analysis of the luteinizing hormone receptor gene in two individuals with leydig cell tumors. American fournal of Medical Genetics 108 148-152.

Dierich A, Sairam MR, Monaco L, Fimia GM, Gansmuller A, LeMeur M \& Sassone-Corsi P 1998 Impairing follicle-stimulating hormone (FSH) signaling in vivo: targeted disruption of the FSH receptor leads to aberrant gametogenesis and hormonal imbalance. PNAS $9513612-13617$.

Gonzales GF 2001 Function of seminal vesicles and their role on male fertility. Asian Foumal of Andrology 3 251-258.

Hamalainen T, Poutanen M \& Huhtaniemi, I 1999 Age- and sex-specific promoter function of a 2-kilobase 5 '-flanking sequence 
of the murine luteinizing hormone receptor gene in transgenic mice. Endocrinology 140 5322-5329.

Hamalainen T, Poutanen M \& Huhtaniemi, I 2001 Promoter function of different lengths of the murine luteinizing hormone receptor gene $5^{\prime}$-flanking region in transfected gonadal cells and in transgenic mice. Endocrinology 142 2427-2434.

Haywood M, Tymchenko N, Spaliviero J, Koch A, Jimenez M, Gromoll J, Simoni M, Nordhoff V, Handelsman DJ \& Allan CM 2002 An activated human follicle-stimulating hormone (FSH) receptor stimulates FSH-like activity in gonadotropin-deficient transgenic mice. Molecular Endocrinology 16 2582-2591.

Hearn MT \& Gomme PT 2000 Molecular architecture and biorecognition process of the cysteine knot protein superfamily: part I. The glycoprotein hormones. Fournal of Molecular Recognition 13 223-278.

Higgins SJ, Burchell JM \& Mainwaring WI 1976 Testosterone control of nucleic acid content and proliferation of epithelium and stroma in rat seminal vesicles. Biochemical fournal $16043-48$.

Hsu SY, Lai RJ, Nanuel D \& Hsueh AJW 1995 Different 5'-flanking regions of the inhibin- $\alpha$ gene target transgenes to the gonad and adrenal in an age-dependent manner in transgenic mice. Endocrinology 136 5577-5586.

Huhtaniemi I 1995 Molecular aspects of the ontogeny of the pituitary-gonadal axis. Reproduction Fertility and Development 7 $1025-1035$.

Ignacak M, Hilczer M, Zarzycki J \& Trzeciak WH 2000 Substitution of M398T in the second transmembrane helix of the LH receptor in a patient with familial male-limited precocious puberty. Endocrine Fournal 47 595-599.

Ignacak M, Starzyk J, Dziatkowiak H \& Trzeciak WH 2002 Study of the family of a patient with male-limited precocious puberty (MPP) due to T1193C transition in exon 11 of LH receptor gene. Fournal of Endocrinological Investigation 25 259-263.

Kananen K, Markkula M, El-Hefnawy T, Zhang F-P, Paukku T, Su JG, Hsueh, AJW \& Huhtaniemi, I 1996 The mouse inhibin $\alpha$-subunit promoter directs SV40 T-antigen to leydig cells in transgenic mice. Molecular and Cellular Endocrinology 119 135-146.

Kumar TR, Wang Y, Lu N \& Matzuk MM 1997 Follicle stimulating hormone is required for ovarian follicle maturation but not male fertility. Nature Genetics 15 201-204.

Laue L, Chan W, Hsueh A, Kudo M, Hsu S, Wu S, Blomberg L \& Cutler G Jr 1995 Genetic heterogeneity of constitutively activating mutations of the human luteinizing hormone receptor in familial male-limited precocious puberty. PNAS 92 1906-1910.

Liu G, Duranteau L, Carel JC, Monroe J, Doyle DA \& Shenker A 1999 Leydig-cell tumors caused by an activating mutation of the gene encoding the luteinizing hormone receptor. New England Fournal of Medicine 341 1731-1736.

Matzuk MM, DeMayo FJ, Hadsell LA \& Kumar TR 2003 Overexpression of human chorionic gonadotropin causes multiple reproductive defects in transgenic mice. Biology of Reproduction 69 338-346.

Muller J, Gondos B, Kosugi S, Mori T \& Shenker A 1998 Severe testotoxicosis phenotype associated with Asp578-> Tyr mutation of the lutrophin/choriogonadotrophin receptor gene. Fournal of Medical Genetics 35 340-341.
Narayan P, Wu C \& Puett D 1995 Functional expression of yoked human chorionic gonadotropin in baculovirus-infected insect cells. Molecular Endocrinology 9 1720-1726.

Risma KA, Clay CM, Nett TM, Wagner T, Yun J \& Nilson JH 1995 Targeted overexpression of luteinizing hormone in transgenic mice leads to infertility, polycystic ovaries, and ovarian tumors. PNAS 92 1322-1326.

Risma KA, Hirshfield AN \& Nilson JH 1997 Elevated luteinizing hormone in prepubertal transgenic mice causes

hyperandrogenemia, precocious puberty, and substantial ovarian pathology. Endocrinology 138 3540-3547.

Roberts VJ, Sawchenko PE \& Vale W 1991 Expression of inhibin/ activin subunit messenger ribonucleic acids during rat embryogenesis. Endocrinology 128 3122-3129.

Robker RL, Russell DL, Yoshioka S, Sharma SC, Lydon JP, O'Malley BW, Espey LL \& Richards JS 2000 Ovulation: a multi-gene, multi-step process. Steroids 65 559-570.

Rosenthal IM, Refetoff S, Rich B, Barnes RB, Sunthornthepvarakul T, Parma J \& Rosenfield RL 1996 Response to challenge with gonadotropin-releasing hormone agonist in a mother and her two sons with a constitutively activating mutation of the luteinizing hormone receptor - a clinical research center study. Fournal of Clinical Endocrinology and Metabolism 81 3802-3806.

Rulli SB, Kuorelahti A, Karaer O, Pelliniemi LJ, Poutanen M \& Huhtaniemi I 2002 Reproductive disturbances, pituitary lactotrope adenomas, and mammary gland tumors in transgenic female mice producing high levels of human chorionic gonadotropin. Endocrinology $1434084-4095$.

Rulli SB, Ahtiainen P, Makela S, Toppari J, Poutanen M \& Huhtaniemi I 2003 Elevated steroidogenesis, defective reproduction organs, and infertility in transgenic male mice overexpressing human chorionic gonadotropin. Endocrinology 144 4980-4990.

Shenker A 2002 Activating mutations of the lutropin/ choriogonadotropin receptor in precocious puberty. Receptors and Channels 8 3-18.

Shinozaki H, Butnev V, Tao Y-X, Ang KL, Conti M \& Segaloff DL 2003 Desensitization of Gs-coupled receptor signaling by constitutively active mutants of the human lutropin/choriogonadotropin receptor. Fournal of Clinical Endocrinology and Metabolism 88 1194-1204.

Sugahara T, Pixley M, Minami S, Pearls E, Ben-Menahem D, Hsueh A \& Boime I 1995 Biosynthesis of a biologically active single peptide chain containing the human common $\alpha$ and chorionic gonadotropin $\beta$ subunits in tandem. PNAS 92 2041-2045.

Themmen APN \& Huhtaniemi IT 2000 Mutations of gonadotropins and gonadotropin receptors: elucidating the physiology and pathophysiology of pituitary-gonadal function. Endocrine Revieres $\mathbf{2 1}$ 551-583.

Wu C, Narayan P \& Puett D 1996 Protein engineering of a novel constitutively active hormone-receptor complex. Fournal of Biological Chemistry 271 31638-31642.

Received 12 November 2004 Accepted 17 December 2004 